\title{
Homograft replacement of aortic valve and ascending aorta in a patient with non-specific giant cell aortitis
}

\author{
GIUSEPPE GULA, ARIELA POMERANCE, MICHAEL BENNET, AND \\ MAGDI H. YACOUB
}

From the Department of Cardiothoracic Surgery, Harefield Hospital; and Department of Histopathology, Harefield and Mount Vernon Hospitals, Middlesex

\begin{abstract}
A case of giant cell aortitis causing ascending aortic aneurysm associated with aortic regurgitation is reported. The aneurysm was excised and the aortic valve replaced using a fresh homograft. The patient has been followed up for three and a half years. There is good evidence of correction of the haemodynamic lesion and no evidence of further arteritis or aneurysmal formation. The pathological and clinical problems of this disease are discussed.
\end{abstract}

Giant cell aortitis is a rare cause of aortic aneurysm. Histological features are similar to those encountered in temporal arteritis and consist of medial inflammatory changes with destruction of the muscular and elastic fibres of the aortic wall. A striking feature of the inflammatory infiltrate is the presence of multinucleate giant cells, usually of Langhans type.

Since it may not be clinically evident, the diagnosis of giant cell aortitis is often first made by the histopathologist after necropsy or operation.

The purpose of this paper is to describe a patient with giant cell aortitis, with resultant ascending aortic aneurysm and aortic regurgitation treated by excision of the aneurysm and homograft replacement of the aortic valve with reimplantation of the coronary ostia into the Dacron graft. The clinical and pathological features of this disease are discussed.

\section{Case report}

A 61-year-old man was admitted to Harefield Hospital because of increasing dyspnoea and an aortic murmur. There was no family history of heart disease. The patient was well until 1970 when he began to hear noises in the ears which were synchronous with the pulse. Since then he had been increasingly conscious of fatigue and thought he was slightly short of breath, especially on stooping. He had no polymyalgia, headache, or chest pain. In
1972, on a routine medical examination, a heart murmur was heard. There was no history of rheumatic fever or venereal disease. He was known to have had a peptic ulcer which gave rise to occasional bleeding.

On examination the jugular pressure was normal, the pulse regular at a rate of 82 a minute and of collapsing type. All pulses were palpable, with prominent carotid pulsations in the neck. The blood pressure was $160 / 60 \mathrm{mmHg}$. There was left ventricular enlargement grade $3 / 4$. Both heart sounds were present, and in the aortic area an ejection systolic murmur grade $2 / 4$ and an early diastolic murmur grade 2/4 were heard. Physical examination otherwise showed no abnormalities.

Laboratory tests showed negative serology for syphilis. The ESR was $4 \mathrm{~mm}$ (Westergren). An electrocardiogram showed $Q R S$ frontal axis of $-30^{\circ}$, sinus rhythm and evidence of left ventricular hypertrophy. The chest $x$-ray picture indicated cardiomegaly with left ventricular configuration. Cardiac catheterisation (right and left) showed a mean wedge pressure of $6 \mathrm{mmHg}$ with an $a$ of 2 and $v$ of 9 ; pulmonary arterial pressure $24 / 5 \mathrm{mmHg}$; aortic pressure $150 / 65 \mathrm{mmHg}$, with no gradient across the aortic valve. Cardiac index was $1.81 / \mathrm{min}$ per $\mathrm{m}^{2}$ with a pulmonary vascular resistance of 2 units. Aortography defined an aneurysm involving the proximal ascending aorta and grade $3 / 4$ aortic regurgitation. The upper margins of the sinuses of Valsalva were not clearly defined. Left ventriculography 
suggested moderate impairment of left ventricular contractility.

The operation was performed using a median sternotomy and employing standard cardiopulmonary bypass with coronary perfusion. A large aneurysm of the ascending aorta involving the sinus region was present. On opening the aneurysm, the aortic valve which was bicuspid in configuration, was grossly regurgitant. The valve was resected and replaced with a fresh 'unstented' aortic homograft. The aneurysm was excised and the aortic continuity was restored using a $30 \mathrm{~mm}$ preclotted Dacron tube, $5 \mathrm{~cm}$ in length, followed by reimplantation of both coronary arteries. Examination of the resected piece of aorta, which measured $10 \times 6 \mathrm{~cm}$ and was slightly thickened, showed multidirectional intimal wrinkling. The resected aortic valve consisted of the fused two coronary cusps, which were $3 \mathrm{~cm}$ long, with a calcified ridge along the middle and the non-coronary cusp which measured $2 \mathrm{~cm}$ in length and was thin.

Microscopically there was distinct old meso- aortitis with scarring, a few chronic inflammatory cell foci, and adventitial thickening with perivascular cuffing by lymphocytes and plasma cells. The intima was irregularly thickened with fibrin deposition on the endothelial surface and atheroma superimposed. Mild cystic medial degeneration was also present in the media. The block from the proximal aorta showed, in addition, a central zone of degenerate looking media bordered by giant cell granulomata (Fig. 1 and 2). There was little medial mucoid change in this piece. The cusps of the aortic valve showed only moderate nodular fibrous thickening at their margins.

After operation the patient made satisfactory progress and was discharged 2 weeks later. Because of his peptic ulcer he was not given steroids. Three and a half years after the operation the patient was well and asymptomatic with normal pulse and blood pressure $(160 / 90 \mathrm{mmHg})$. On auscultation there was a soft systolic murmur and a soft early diastolic murmur in the aortic area. There were no clinical or
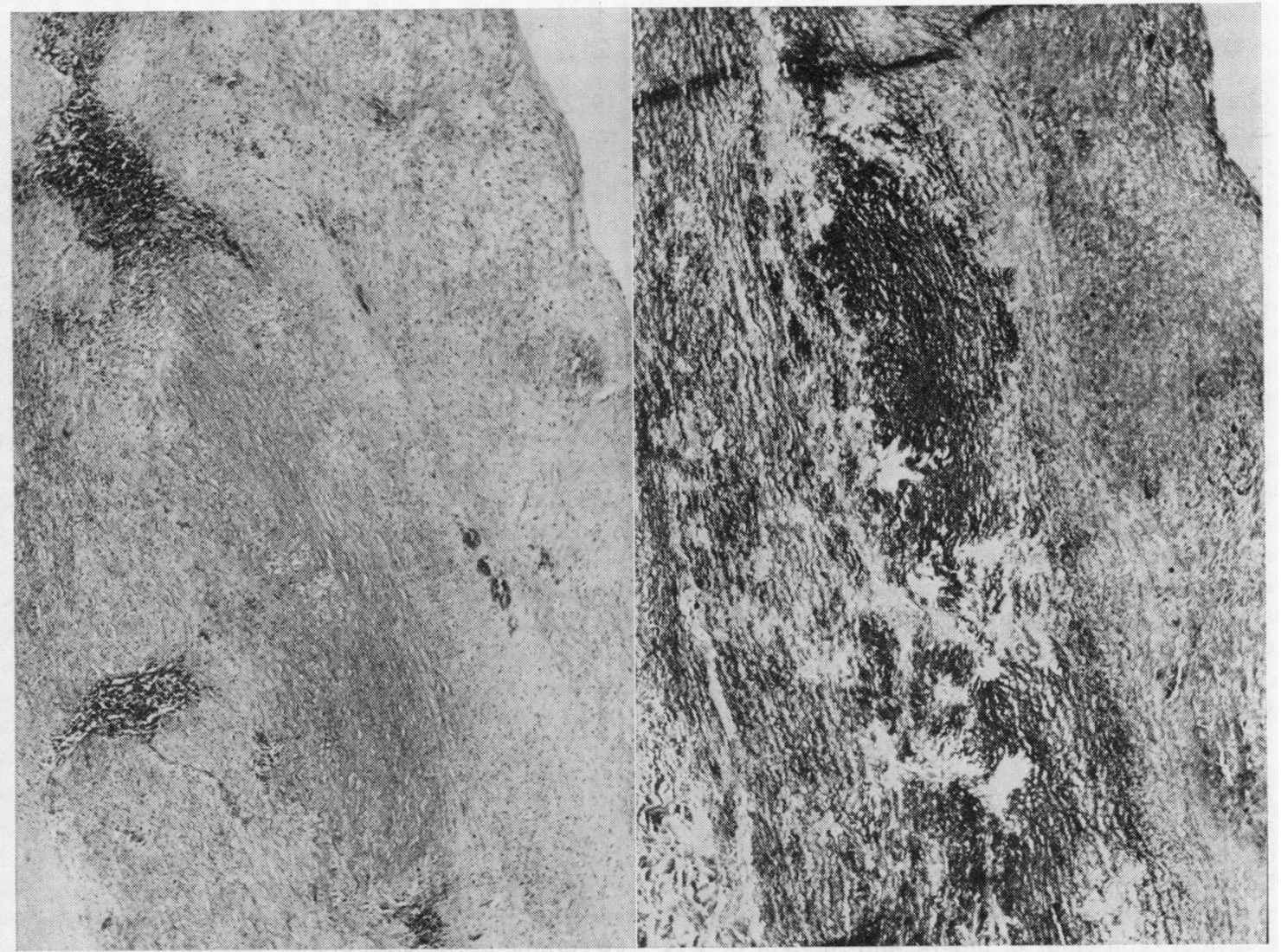

Fig. 1 Section from proximal aorta showing well demarcated eosinophilic areas of degeneration in media and focal inflammatory cell infiltration [(a) Haematoxylin and eoxin; (b) Weigert elastic-van Gieson; both $\times 25]$. 


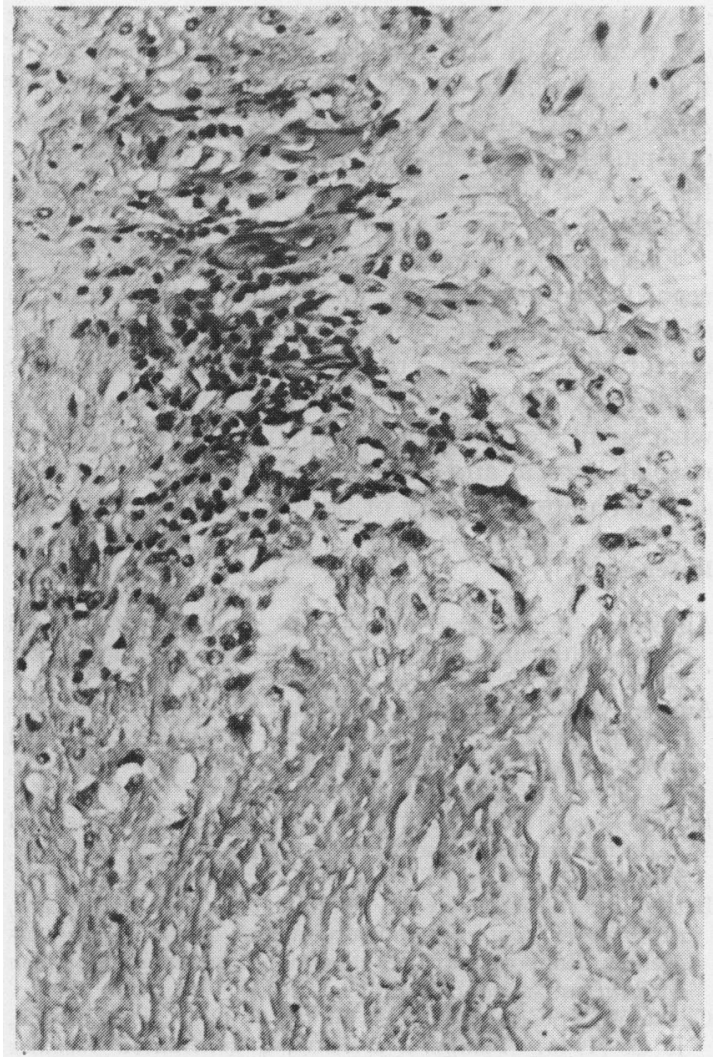

Fig. 2 Higher power view of the inflammatory infiltrate upper margin, showing several multinucleate giant cells among the mononuclear cells. (Haematoxylin and eosin $\times 165$.)

radiological abnormalities in the chest and the electrocardiogram showed sinus rhythm with mild left ventricular hypertrophy. Left heart catheterisation and coronary and renal angiography were performed in order to assess the possible involvement of such arteries. A cineangiocardiogram indicated a well-contracting left ventricle, with a slightly raised end systolic volume. The aortic root injection confirmed only a minimal trace of aortic regurgitation with a Dacron graft in place. The arch and the descending thoracic aorta were normal. Coronary and renal angiograms were normal.

\section{Discussion}

Aortitis with giant cells can occur in some infective conditions, notably syphilis and tuberculosis, as well as in rheumatoid arthritis, Reiter's syndrome, scleroderma, and ankylosing spondylitis (Marquis et al., 1968; Hudson, 1965-70). The aorta is also one of the vessels commonly involved in giant cell arteritis (Sproul and Hawthorne, 1937; Cooke et al., 1946; Magarey, 1950; McMillan, 1950; Bettez and Delorme, 1970).

In addition, infarct-like lesions surrounded by chronic inflammatory cells and giant cells may be found limited to the aorta and great vessels (Heggtveit et al., 1963) in the condition referred to as 'idiopathic medial aortopathy' (Marquis et al., 1968).

Whatever the aetiology, the aortic medial inflammation and necrosis will ultimately result in scarring of the media with loss of its elastic properties. The affected aorta tends to enlarge and, according to Laplace's law, is more liable to formation of aneurysm. If hypertension is present, dissection can take place (Harris, 1968; Grivaux et al., 1973), with possible rupture and sudden death (Ainsworth and Gresham, 1961; Garret, 1963). Bettez and Delorme (1970) in a review of the reports on giant cell aortitis found moderate aortic dilatation in only 5 of 29 collected cases, while an aneurysm developed in 24 with 2 cases of fatal rupture. The lesion was localised in the thoracic or abdominal aorta in 17 cases, while in 12, other arteries were also affected.

The uncomplicated lesion is silent and can be detected only microscopically at necropsy. When significant dilatation or aneurysm of the ascending aorta occurs, the clinical picture is dominated by the signs of aortic regurgitation resulting from distortion of the aortic valve, as in our patient.

The clinical diagnosis of giant cell arteritis with aortic involvement, though difficult, can be suspected in case of rapidly evolving aortic regurgitation associated with temporal arteritis or polymyalgia in patients with negative serology, a raised ESR, and no history of rheumatic fever. The diagnostic value of concomitant temporal arteritis is not in doubt. Harris (1968), in 11 cases of dissecting aneurysms associated with giant cell aortitis, found a positive history of temporal arteritis in 5 .

Our patient presented with the signs of aortic regurgitation without a history suggesting temporal arteritis, and temporal artery biopsy had, therefore, not been performed. Serology for syphilis was negative and ESR normal. There had been no symptoms suggesting polymyalgia or other collagen disease. Though we cannot exclude the possibility that the aortitis was part of a giant cell arteritis we feel that the diagnosis is most likely to be the form of isolated giant cell aortitis, a subgroup of idiopathic medial aortopathy of Marquis et al. (1968). Surgical treatment of giant cell aortitis has been reported only on few occasions. The first concerned a 30- 
year-old Negro woman with an aneurysm of the proximal ascending aorta associated with severe aortic regurgitation (Austen and Blennerhassett, 1965). At operation the aortic intima showed small white nodules while the aortic valve was normal. The aneurysm and aortic valve were excised and replaced by a Starr prosthesis, aortic continuity being restored with a Teflon graft. The diagnosis was made postoperatively on the basis of the microscopical findings. The patient was followed for 6 months during which time she remained well. Kent and Arnold (1967) excised a dissecting aneurysm of the descending thoracic aorta in a 35-year-old man who had complained of haemoptysis associated with productive cough and chest pain. At operation multiple raised nodules, varying in diameter from 1 to $15 \mathrm{~mm}$, were found in the aorta. The diagnosis was also made microscopically. The postoperative course was complicated by myocardial infarction, probably resulting from involvement of coronary arteries. At follow-up 5 months later, dyspnoea and angina were present on exertion but the radiographic appearances of the heart and mediastinum were normal.

Zumbro, Henley, and Treasure (1975) have reported the case of a 7-year-old Korean boy who underwent successful surgical excision of saccular aneurysm of the ascending aorta. There was no past history of trauma or infective diseases. Chest $x$-ray film had been normal one year previously. The aneurysm was discovered on a routine chest film taken because of respiratory infection and removed by lateral aortorrhaphy with cardiopulmonary bypass. The patient remained well during the 6 months of follow-up.

In our patient surgical correction was accomplished by the excision of the aneurysm and aortic valve, followed by insertion of an aortic valve homograft. Aortic continuity was restored using a Dacron tube with reimplantation of both coronary arteries. The homograft was fixed in place by two suture lines, with a technique similar to that described by Barratt-Boyes (1965), Ross (1968), and Ross and Yacoub (1969), and the top of the homograft was fixed to the Dacron tube. At operation the aortic intima did not show the nodular lesions seen by Austen and Blennerhassett (1965) and Kent and Arnold (1967).

The diagnosis was based on the histological findings of necrotic areas and meso-aortitis with giant cells. Follow-up for three and half years has shown no evidence of progressive disease.

In patients with temporal arteritis the use of steroids has been suggested in order to prevent possible progression of the disease (Harris, 1968). None of the patients treated surgically had been on steroids after operation, and there was no evidence of progress of the disease during the period of follow-up which varied from 5 months (Kent and Arnold, 1967) to $3 \frac{1}{2}$ years (present case). In addition our patient gave a history of peptic ulcer which we felt was a contraindication to long-term steroid therapy.

Despite his aortitis and aneurysm which are regarded by many workers as a contraindication to the use of homograft, our patient, $3 \frac{1}{2}$ years after the operation is well and the homograft is functioning efficiently. However, the late prognosis of patients with giant cell aortitis is still unknown and only regular clinical and radiological follow-up will give a better understanding of the course of the disease.

\section{References}

Ainsworth, R. W., and Gresham, G. A. (1961). Giant-cell aortitis with rupture of the aorta. Fournal of Pathology and Bacteriology, 82, 203.

Austen, W. G., and Blennerhassett, J. B. (1965). Giant-cell aortitis causing an aneurysm of the ascending aorta and aortic regurgitation. New England fournal of Medicine, 272, 80.

Barratt-Boyes, B. G. (1965). A method for preparing and inserting a homograft aortic valve. British fournal of Surgery, $52,847$.

Bettez, P., and Delorme, F. (1970). Anéurisme disséquant, rupture de l'aorte, secondaire à une aortite à cellules géantes. Rapport d'un cas et revue de la literature. Union Médical du Canada, 99, 1621.

Cooke, W. T., Cloake, P. C. P., Govan, A. D. T., and Colbeck, J. C. (1946). Temporal arteritis; a generalised vascular disease. Quarterly fournal of Medicine, 15, 47.

Garret, R. (1963). Chronic diffuse giant cell mesaortitis with dissecting aneurysm and rupture. American fournal of Clinical Pathology, 38, 406.

Grivaux, M., Soulie, J., Diallo, A., Chevalley, J., and Nouchy, E. (1973). Artérite temporale et hématome disséquant de l'aorte. Temporal arteritis and dissecting aneurysm of the aorta. Semaine des Hopitaux de Paris, 49, 1707.

Harris, M. (1968). Dissecting aneurysm of the aorta due to giant cell arteritis. British Heart fournal, 30, 840.

Heggtveit, H. A., Hennigar, G. R., and Morrione, T. G. (1963). Panaortitis. American fournal of Pathology, 42, 151.

Hudson, R. E. B. (1965-70). Cardiovascular Pathology. Arnold, London.

Kent, D. C., and Arnold, H. (1967). Aneurysm of the aorta due to giant cell aortitis. Successful surgical correction. Fournal of Thoracic and Cardiovascular Surgery, 53, 572.

McMillan, G. C. (1950). Diffuse granulomatous aortitis with giant cells associated with partial rupture and dissection of the aorta. Archives of Pathology, 49, 63.

Magarey, F. R. (1950). Dissecting aneurysm due to giant-cell aortitis. Fournal of Pathology and Bacteriology, 62, 445.

Marquis, Y., Richardson, J. B., Ritchie, A. C., and Wigle, E. D. (1968). Idiopathic medial aortopathy and arteriopathy. American fournal of Medicine, 44, 939.

Ross, D. N. (1968). Homograft replacement of the aortic valve. Surgery, 63, 382.

Ross, D. N., and Yacoub, M. H. (1969). Homograft replacement of the aortic valve. A critical review. Progress in Cardiovascular Diseases, 11, 275.

Sproul, E. E., and Hawthorne, J. J. (1937). Chronic diffuse mesaorteritis. American fournal of Pathology, 13, 311. 
Zumbro, G. L., Henley, L. B., and Treasure, R. L. (1975). Requests for reprints to Magdi H. Yacoub, Esq., matous aortitis in a child. fournal of Thoracic and Cardio- F.R.C.S., Harefield Hospital, Harefield, Uxbridge, vascular Surgery, 69, 397. Middlesex UB9 6JH. 